\title{
Polysèmes
}

Revue d'études intertextuelles et intermédiales

\section{Le roman moderniste et la musicalisation de la fiction dans l'esthétique de Dorothy Richardson}

The Modernist Novel and the Musicalization of Fiction in Dorothy Richardson's Aesthetics

Ivana Trajanoska

\section{OpenEdition}

\section{Journals}

Édition électronique

URL : http://journals.openedition.org/polysemes/1594

DOI : 10.4000/polysemes.1594

ISSN : 2496-4212

Éditeur

SAIT

Référence électronique

Ivana Trajanoska, «Le roman moderniste et la musicalisation de la fiction dans l'esthétique de

Dorothy Richardson », Polysèmes [En ligne], 16 | 2016, mis en ligne le 15 novembre 2016, consulté le

30 avril 2019. URL : http://journals.openedition.org/polysemes/1594; DOI : 10.4000/polysemes.1594

Ce document a été généré automatiquement le 30 avril 2019.

Polysèmes 


\section{Le roman moderniste et la musicalisation de la fiction dans l'esthétique de Dorothy Richardson}

The Modernist Novel and the Musicalization of Fiction in Dorothy Richardson's Aesthetics

Ivana Trajanoska

1 L'entreprise littéraire de Dorothy Richardson, représentée par son roman en treize volumes, Pilgrimage (ci-après $P$ dans les références), publié de 1915 à 1967 (le douzième volume a été publié dans l'édition complète de Pilgrimage en 1938 et le treizième volume, inachevé, a été publié après la mort de Richardson dans l'édition complète de J.M. Dent en 1967), propose une interprétation féministe des rôles masculins et féminins. Ce sujet central devient un terrain fertile qui mène à une expérimentation technique et qui permet à l'écrivain de transformer l'écriture traditionnelle. L'effort de Richardson pour décrire la conscience féminine, et pour réécrire le monde à travers celle-ci, a influencé son style et l'a amenée à rejeter les techniques conventionnelles du roman réaliste et les traditions du roman anglais du XIX ${ }^{\mathrm{e}}$ siècle. Comme Hanscombe le fait remarquer :

Nevertheless, like all radicals, Richardson is ambivalent at heart recognizing that a work of fiction must take its place among its predecessors. Therefore, in her own terms, she is forced to make an assessment of the tradition and to take a theoretical stand on the question of the structure and the function of the novel. And because of her conviction that the traditional conventions express an overwhelmingly masculine world view, she must transform those conventions to accommodate Miriam's world view. For Richardson, therefore, words themselves become highly charged with ambivalence. The higher insights are above and beyond language. (Hanscombe 1979, 10)

Or, l'ambivalence envers le langage dont parle Hanscombe serait mieux comprise si l'on prenait en compte le rôle de la musique dans le texte et la musicalisation de la fiction que Richardson met en œuvre. Une syntaxe et une ponctuation inhabituelle; l'emploi du temps présent et du passé au sein d'une même phrase ; l'emploi du blanc typographique 
et des italiques ; des jeux de mots et des calembours ; des allitérations et des assonances ; des répétitions et des variations; des références à la musique classique, religieuse et folklorique; la description de morceaux de musique classique et des différentes manières de les interpréter, essentiellement au piano ; des références aux compositeurs, aux œuvres que ces musiciens ont composées, à des morceaux sans titre ou sans nom de compositeur; des paroles d'hymnes, des chansons et des poèmes; l'évocation de la qualité des voix et de différentes performances musicales, sont autant de signes de l'effort de Richardson à la fois pour opérer une musicalisation du roman et pour rompre avec le roman traditionnel du XIX ${ }^{e}$ siècle.

Pour cerner la notion de musicalisation de la fiction chez Richardson, nous nous appuyons sur la définition proposée par Werner Wolf qui, prenant en compte l'historique du concept $\mathrm{t}^{1}$, la définit comme un cas particulier de l'intermédialité musico-littéraire, où la musique n'est pas seulement un thème du roman mais représente un modèle d'imitation adopté par l'écrivain de manière délibérée : «[...] if we want to speak of a musicalization that deserves this name, there must be more than thematization of music [...]. It consists in an (in most cases) intentional shaping of the discourse (affecting, e.g., the linguistic material, the formal arrangement or structure of the narrative, and the imagery used)» (Wolf 1999, 51, 60). En outre, selon Wolf, la musicalisation de la fiction aboutit à une expérience musicale pendant la lecture : "As a result, the reader has the impression that [...] the presence of music can indirectly be experienced while reading " (60). Dans cet article, nous examinerons tout d'abord l'esthétique de Richardson, exposée dans ses articles, ses essais, et dans Pilgrimage, qui développe les principes sur lesquels le roman moderniste doit se fonder selon l'auteur. Puis, nous lierons ces principes à la question de la musicalisation du roman chez Richardson, en nous concentrant notamment sur la ponctuation et l'accompagnement musical et en démontrant leur importance au sein de Pilgrimage. Cette problématique fait également apparaître le lien entre le motif de la traversée et Pilgrimage. La traversée comme motif dans la littérature est souvent associée au voyage et à la quête, aux passages entre différents genres littéraires, mais aussi de la littérature canonique à l'expérimentation littéraire. Pilgrimage est un roman qui parle de la quête identitaire de la protagoniste, Miriam Henderson, et de son pèlerinage spirituel vers la découverte de soi et de la joie. Pilgrimage est aussi un cas particulier qui se situe entre la fiction et l'autobiographie. De plus, Richardson, grâce à son œuvre romanesque, est devenue la pionnière de la technique moderniste du « courant de conscience » et a ouvert la voie de l'expérimentation moderniste. Pilgrimage représente également une traversée intermédiale. Le roman met en œuvre un passage d'une forme d'art à l'autre: de la littérature à la peinture, au cinéma, et à la musique. Cette traversée riche mais exigeante, est ouverte aux lecteurs prêts à collaborer.

\section{Richardson et le roman moderniste}

4 L'esthétique de Richardson est un sujet passionnant mais assez peu étudié. Faute de références directes à la musicalisation de la fiction dans son esthétique, l'étude de sa réflexion sur le roman moderniste nous permettra de saisir les raisons pour lesquelles Richardson s'est appuyée sur la musique dans la construction de son roman et dans le développement de sa technique novatrice, encore incomprise au moment de la parution du roman, et ainsi de comprendre son projet artistique dans son ensemble. L'auteur a exprimé ses idées, parfois contradictoires, sur l'écriture et sur le roman moderniste dans 
ses nombreux articles, critiques de romans et essais publiés de 1906 à 1939 sur différents sujets, dans des revues comme Crank, Adelphi et Vanity Fair, ainsi que dans les vingt-trois articles sur le cinéma publiés dans la revue Close Up. Cependant, Richardson a clairement exprimé l'incapacité du roman traditionnel à donner forme au sujet qui l'intéressait: " The material that moved me to write would not fit the framework of any novel I had experienced. I believed myself to be [...] intolerant of the romantic and the realist novel alike. Each [...] left out certain essentials and dramatized life misleadingly. Horizontally [...]. Always [...] one was aware of the author and applauding, or deploring, his manipulations » (Hanscombe 1979, 3).

En exposant sa technique dans ses articles, Richardson remarque que, dans les premières phases de la rédaction de Pilgrimage, elle s'est rendu compte qu'elle parlait de la protagoniste dans son roman tout en se demandant qui avait l'autorité nécessaire pour la décrire : "There she was as I first saw her, going upstairs. But who was there to describe her?» (Morgan 1931, 400). Dans Pilgrimage, Richardson voulait présenter sa protagoniste objectivement et non pas à travers la voix d'un narrateur qui guide le lecteur et le place ainsi en position inférieure. Elle a ainsi rejeté le narrateur conventionnel, l'autorité qu'il impose au lecteur et son omniprésence dans les romans traditionnels: "Always, for charm or repulsion, for good or ill, one was always aware of the author and applauding, or deploring, his manipulations » (Richardson 1959, 19). Montrer la vie (« life in its own right at first hand») (Morgan 1931, 400), c'est ce que l'écrivain doit faire, selon Richardson. Alors, pour réduire cette autorité narrative qui empêche l'écrivain de représenter la vie directement, Richardson accorde au lecteur un rôle collaboratif et le place au même niveau que l'écrivain. Elle est persuadée que le lecteur est à même de collaborer avec l'écrivain afin de découvrir la vie, «the quality of life as it is being lived by her character ». "She strove, in addition, to make her style inseparable from that of her character's consciousness » (Gillespie 1990, 395).

Miriam Henderson, la protagoniste principale du roman, évoque également le roman traditionnel qui, selon elle, ne révèle que la vérité de l'écrivain et non la vérité dans l'absolu. Dans les conversations entre Miriam et Hypo (version fictive de H.G. Wells), on comprend que pour Miriam, les écrivains, sous prétexte de révéler la vérité de la vie, ne révèlent qu'une part de vérité sur leur vie. Lorsqu'elle devient écrivain, Miriam cherche une autre voie, une façon de mettre l'écrivain et le lecteur sur un pied d'égalité, «side by side » $(P 1,333)$. Ceci n'est pas simplement une main tendue au lecteur mais fait partie intégrante de son écriture. Le style et la technique que Richardson emploie, ainsi que sa recherche d'une nouvelle méthode littéraire, montrent son amour pour la richesse et les possibilités du langage, mais également sa méfiance vis-à-vis de sa capacité à représenter la réalité. Dans « Data for a Spanish publisher » (Richardson 1989), Richardson évoque l'amour qu'elle voue depuis sa jeunesse aux mots: "Even so, there was still the fascination of words, of their sturdy roots, their growth and transformation, and the strange drama of the pouring in from every quarter of the globe of alien words assimilated and modified to the rhythm of our own speech, enriching its poetry and making its spelling and its pronunciation the joy of those who love it and despair of all others » (155).

7 En 1939, Richardson écrit une critique de Finnegans Wake de Joyce intitulée «Adventure for Readers » où elle fait référence aux possibilités que le roman offre aux lecteurs, possibilités qui transforment la lecture en aventure. Cet article met en corrélation la tradition poétique et la tradition romanesque et insiste sur la valeur et les innovations 
des romans modernes. S'inspirant de la célèbre définition de la poésie selon Wordsworth, Richardson offre la sienne : "[Poetry is] the result of passion recollected in tranquillity " (Richardson 1990, 425, l'auteur souligne). Elle remarque que les romanciers contemporains, c'est-à-dire ceux de la fin du $\mathrm{XIX}^{\mathrm{e}}$ et du début $\mathrm{du} \mathrm{Xx}^{\mathrm{e}}$ siècle, ont détruit cette « effusion » dont Wordsworth parle : « the product this poet names, with scientific accuracy, an "effusion" " (Richardson 1990, 425). Ce que ces romans offrent aux lecteurs, c'est principalement " de l'excitation et du suspense », et, en mettant l'accent sur l'action et l'intrigue, ils se sont complètement détachés de la poésie. Selon Richardson, le rôle de l'écrivain est de présenter son protagoniste comme spectateur plutôt que comme participant et de trouver des outils adaptés pour ralentir le rythme des événements de l'histoire afin que ceux-ci puissent à la fois être perçus par le protagoniste et modifiés par ses pensées. Le mérite du «nouveau » roman, selon Richardson, est sa qualité poétique qui lui permet de rendre le temps, l'espace et l'identité du protagoniste « immatériels ». Le lecteur plonge dans le roman moderne et il se trouve comme perdu en pleine mer (Richardson 1990, 426). Le roman moderniste doit être comme la poésie où chaque terme est important et contribue à la formation de l'image d'ensemble, mais l'omission de n'importe quelle partie ne diminue pas son pouvoir (Richardson 1990, 426).

Une autre caractéristique importante du roman moderniste selon Richardson concerne l'influence de l'écrivain sur le texte: «[his] signature is closely inscribed across every sentence » (Richardson 1990, 426). Ce qu'elle remarque, chez Joyce en particulier, c'est qu'on retrouve son empreinte dans chaque mot. Elle avoue qu'il exige beaucoup de son lecteur en raison de ses références à d'autres arts que la littérature, de ses jeux de mots, de son mélange de mots anciens et modernes, de slogans, de comptines et de phrases qui sont des mots familiers phonétiquement adaptés à de nouvelles intentions. En s'appuyant sur Walter de la Mare ("When poetry is most poetic, when its sounds, that is, and the utterance of them, and when its rhythms rather than the words themselves are its real if cryptic language, any other meaning, however valuable it may be, is only secondary matter", Richardson 1990, 428), Richardson propose aux lecteurs de Finnegans Wake "d'écouter " le roman: " not so much [what] Joyce says, as [the] lovely way he says it, [the] rhythms and undulating cadences of the Irish voice, with its capacity to make every spoken word a sentence with parentheses and to arouse, in almost every English breast, a responsive emotion » (Richardson 1990, 428). Richardson ajoute : « Let us take the author at his word. Really release consciousness from literary preoccupation and prejudices, from the self-imposed task of searching for superficial sequences in stretches of statement regarded horizontally, or of setting things upright and regarding them pictorially, and plunge, provisionally here and there; enter the text and look innocently about » (Richardson 1990, 428).

Dans la préface à Pilgrimage de 1938, Richardson met sa technique en relation avec celle des autres modernistes célèbres comme Marcel Proust, Henry James, James Joyce et Virginia Woolf. Ce qu'elle identifie comme «le manifeste» du roman moderniste est la théorie que Henry James a exposée dans « Wilhelm Meister» :

In the novel, reflections and incidents should be featured; in drama, character and action. The novel must proceed slowly, and the thought-processes of the principal figure must, by one device or another, hold up the development of the whole... The hero of the novel must be acted upon, or, at any rate, not himself the principal operator [...] and all the incidents are, in a certain measure, modelled according to [his] thoughts. (Richardson 1990, 431) 
10 Pilgrimage était pour Richardson « une aventure » sur un nouveau chemin solitaire, «a fresh pathway », « a lonely track » (Richardson 1990, 430) qui allait substituer à la forme d'écriture unidirectionnelle qu'était le roman une relation complexe entre l'écrivain et le lecteur: "The writer, whatever his struggles, is handling a medium he has used from infancy onwards and whose arduous acquisition and final mastery he has long since forgotten. It lies, ready for use, stored up within him in fragments each of which is a living unit complete in form and significance. Within this medium the reader is also at home » (Richardson 1998, 198). Richardson était sceptique quant au statut accordé aux écrivains qui mettent les lecteurs en position d'infériorité : «Readers are far too modest. Always they regard themselves as recipients, never as donors » (Richardson 1934, 94). Pour elle, la lecture est aussi créative que l'écriture. La lecture et l'écriture sont des actes complémentaires: "while subject to the influence of a work of art, we are ourselves artists, supplying creative collaboration in the form of a reaction of the totality of our creative and constructive and disinterested being " (Richardson 1934, 94). Son désir était de produire un roman qui permette au lecteur d'assumer ce rôle collaboratif qui lui appartient, un roman qui utilise le langage comme un médium commun au lecteur et à l'écrivain.

11 Pour Richardson, comme pour sa protagoniste, le pèlerinage conduit à la vocation d'écrivain. L'écriture devient alors le centre de sa vie: "The small writing-table in my attic became the center of my life » (Richardson 1989, 139). Pour Miriam aussi, l'écriture est une tâche sacrée : « To write is to forsake life. Every time I know this, in advance. Yet, whenever something comes that sets the tips of my fingers tingling to record it, I forget the price; eagerly face the strange journey down and down to the center of being. And the scene of labour, when I am back in it, alone, has become a sacred place " $(P 4,609)$. L'écriture représente aussi le centre de ce roman circulaire qui s'achève au moment où le personnage commence à écrire le roman que l'on a lu. Cependant, pour elle et pour l'écrivain, l'écriture elle-même, et surtout l'écriture du «canon », n'est pas capable de représenter la «vérité ». Richardson se tourne alors vers la musique pour donner une qualité poétique au roman et pour créer un lien entre l'écrivain et le lecteur. La musicalisation de la fiction est aussi une forme de traversée elle-même entre le langage qui ne lui suffisait pas pour exprimer ce qu'elle pensait être le vrai sujet d'un roman et la musique comme idéal de vérité ultime.

\section{La musicalisation de Pilgrimage}

Dans le roman, l'écriture et la musique sont étroitement liées. Dès le premier volume, Miriam annonce son dessein de devenir écrivain en répondant à son professeur qui lui demande ce qu'elle pense faire de sa vie: «Miriam had answered at once with a conviction born that moment that she wanted to "write a book" » $(P 1,80)$. Dans Backwater, sa sœur lui propose de commencer à écrire : « Have you ever thought of committing your ideas to paper? » $(P 1,268)$. Au cours de son pèlerinage, Miriam lit énormément et façonne ses idées sur l'écriture et la lecture. Ces idées ne sont pas figées, elles changent et évoluent à mesure qu'elle-même change et mûrit. En outre, l'écriture est très souvent liée à la musique, comme par exemple dans Honeycomb : « If only she could make Eve see what a book was... a dance by the author, a song, a prayer, an important sermon, a message » ( $P 1,385)$. Son entourage remarque son sens du rythme: "You are like an expressive metronome" » $(P 1,216)$. Et lorsque Miriam pour la première fois exprime son désir 
d'écrire un livre, c'est pendant la leçon de musique à l'école. À travers son pèlerinage, Miriam comprend qu'elle doit être simultanément spectatrice et protagoniste pour pouvoir écrire. En même temps, elle se forge peu à peu son point de vue sur le langage, les mots et leur impuissance à livrer la vérité : " "All that has been said and known in the world is in language, in words [...]. Then no one knows anything for certain" » $(P 1,99)$. Miriam identifie le défaut des mots : " That is the curse of speech, its inability to express several things simultaneously " $(P 4,164)$. Elle aspire alors à un au-delà de la littérature pour trouver le moyen d'exprimer ce que les mots ne peuvent dire; elle cherche comment dépasser les limites linguistiques et exprimer l'ineffable, comment rendre au roman ce qui lui manque, ce qui n'a pu être intégré : « The torment of all novel is what is left out » $(P 4,239)$, d'où son ambivalence envers le langage, selon Hanscombe.

Pour rendre au roman ce qui a été omis, Richardson s'appuie sur la musique. L'usage de la ponctuation, lié à la musique, traduit l'effort que fait Richardson pour permettre au lecteur de collaborer avec elle et au texte de « susciter et d'affecter » le lecteur à son tour (Richardson 1990, 415). Il marque ce que Wolf a décrit comme « intentional shaping of the discourse » (Wolf 1999, 60) dans la fiction musicalisée.

\section{La ponctuation}

14 La rupture avec la ponctuation traditionnelle est facilement perceptible dans Pilgrimage. L'écrivain utilise des points de suspension, des tirets courts et longs. Les critiques ont reproché à Richardson cette initiative, car elle rendait Pilgrimage "illisible", selon eux (Richardson 1990, 431). Dans la préface de Pilgrimage, Richardson essaie de justifier son emploi de la ponctuation en termes de genre : « Feminine prose, [...] should properly be unpunctuated, moving from point to point without formal obstructions " (Richardson 1990, 431). Dans son article sur la ponctuation, Richardson évoque la signification et le pouvoir de la ponctuation en dehors de l'influence du genre et lui accorde une importance essentielle. En faisant référence aux manuscrits anciens qui n'étaient pas ponctués en dehors de l'emploi rare du point, Richardson écrit que l'omission de la ponctuation permet au lecteur de connaître plus facilement le style de l'écrivain. En outre, le lecteur a tendance à ponctuer lui-même pendant qu'il lit. Ce procédé encourage l'écoute, c'est-à-dire que le lecteur commence à écouter le texte. Ainsi, ses facultés intellectuelles et sa sensibilité sont également stimulées et entrent en harmonie :

It is at this point that he begins to be aware of the charm that has been sacrificed by the systematic separation of the phrases. He finds himself listening. Reading through the ear as well as through the eye. [...] But in the slow, attentive reading demanded by unpunctuated texts, the faculty of hearing has its chance, is enhanced until the text speaks itself. And it is of this enhancement that the strange lost charm is born. Quite modest matter, read thus, can arouse and fuse the faculties of mind and heart. (Richardson 1990, 415)

15 Selon l'auteur, la ponctuation traditionnelle réduit la contribution du lecteur au minimum et empêche toute liberté d'expression. Même si le lecteur est soulagé du fardeau que la lecture collaborative impose, l'acte de lecture est complètement "dévitalisé » et devient plus "mécanique ». Le texte ponctué de manière traditionnelle n'invite pas le lecteur à se laisser aller: "to yield all we are and suffer change" (Richardson 1990, 415). Pour Richardson, la prose de Henry James est le meilleur exemple du rôle que peut jouer la ponctuation: «[to be] pace-maker for the reader's creative 
consciousness » (Richardson 1990, 416) ; la ponctuation confère " une musicalité au texte » (Richardson 1990, 416): « So rich and splendid is the fabric of sound he weaves upon the appointed loom, that his prose, chanted to his punctuation, in an unknown tongue, would serve as well as a mass-in D minor » (416). La virgule, ajoute-elle, a pour rôle de mettre en place le ton et le rythme : « it clears meaning and sets both tone and pace » (417).

\section{L'accompagnement musical dans Pilgrimage}

Entre 1927 et 1933, Richardson a publié une vingtaine d'articles dans la revue de cinéma, Close Up. Dans ces articles, dont la majorité fait partie de la chronique régulière "Continuous Performance», Richardson expose son esthétique de l'art cinématographique où elle parle également de la musique et de sa signification au cinéma. On y trouve des concepts tels que la contemplation, la conscience créative, la collaboration du spectateur et du spectacle, l'association, le silence, l'accompagnement musical, le jeu continu, etc. La plupart de ces concepts sont aussi exposés dans Pilgrimage, en particulier lorsque Miriam et son ami écrivain Hypo s'adonnent à de longues conversations sur l'art et l'écriture. Nous pouvons donc, prudemment, établir des analogies valides entre musique et écriture dans le cas de Pilgrimage, comme Laura Marcus l'a fait à propos du concept de "jeu continu». Dans son introduction à "Continuous Performance: Dorothy Richardson", dans Cinema and Modernism, Laura Marcus met l'accent sur le concept de "jeu continu» ("continuous performance») qui est aussi important pour l'esthétique cinématographique que pour Pilgrimage. Selon Marcus, le terme « jeu/projection continu(e) » désigne un processus continu de projection filmique et de "spectating ", qu'elle relie à Pilgrimage et qu'elle oppose au «jeu unique » ou à la " projection unique » dans la salle de spectacle : « The film's "continuous performance" is also "a continuous miracle of form in movement". [...] It is striking that for both novel sequence and film column Richardson insisted upon overall titles-Pilgrimage and "Continuous Performance" respectively-which would act as containers for series that were themselves open-ended and unbordered" (Marcus 1998, 151-152). De surcroît, Marcus met en relation la technique du courant de conscience que Richardson a développée et l'écran cinématographique et ce, à travers la collaboration du lecteur :

Richardson rejected the label "stream-of-consciousness", applied to Pilgrimage from the outset, though the narrative is certainly marked by its immersion in the heroine's consciousness as it moves in and out of engagement with scenes, events, and people. Space, movement, light and reflections are primary foci of attention; while the perceiving consciousness is centrally important, it is shown in a state of flux and process. [...] Consciousness becomes a screen (rather than a stream) on and through which the past and the future project their shapes and series. [...] Through the production of fiction as film, these modernist writers [Richardson and Woolf in particular] sought to remove from the scene the omniscient author, identified with the closed and hegemonic world of nineteenth-century fiction. In so doing, they transcribe a ghostly realism, a spectral mimesis, which anticipates Christian Metz's characterization of the film as signifying " the presence of an absence ". (Marcus 1998, 152)

17 Marcus s'appuie sur ce que Richardson écrit sur l'art, l'écriture et la conscience : «The process may go forward in the form of a conducted tour, the author leading, visible and audible, all the time. Or the material to be contemplated may be thrown upon a screen, the author out of sight and hearing " (Richardson 1998, 154). Le même thème est abordé dans les articles de Richardson constituant la série "Continuous Performance», où elle 
écrit que le film offre toute liberté au spectateur : « an unlimited material upon which the imagination of the onlooker could get to work unhampered by the pressure of a controlling mind that is not his own mind (Marcus 1998, 154). De plus, Richardson ellemême établit un parallèle entre le film et le roman. Selon elle, donner des informations directes dans un film et dans un roman nuit à leur qualité : «And if the direct giving of information in captions is the mark of a weak film, the direct giving of information in a play or a novel is the mark of a weak novel or play " (Richardson 1998, 165). Pour présenter "la vie de l'esprit directement» ("the life of the spirit directly»), ce que le film peut aussi bien faire que le roman qui présente la vie directement ( in its own right at first hand »), tous deux ont besoin d'être accompagnés d'un minimum d'informations (« [a] minimum of informative accompaniment») (Richardson 1998, 165) pour éviter de détruire la relation spectateur-acteur ( $«$ the inner relationship between audience and players ») (Richardson 1998, 161). Ce dont ils ont besoin pour susciter la coopération de la conscience créatrice du spectateur, c'est d'un accompagnement musical.

Dans son article "Musical Accompaniment» publié dans la série "Continuous Performance ", Richardson désigne comme accompagnement musical le jeu du piano dans la salle de spectacle qui accompagne la projection des films muets (Richardson 1927, 162) : «His playing was a continuous improvisation varying in tone and tempo according to what was going forward on the screen » (Richardson 1927, 162). L'accompagnement musical assure la coopération du public. Une telle coopération ne peut avoir lieu que si le public est d'abord capable de s'oublier en tant que public: "This takes power. Not force or emphasis or noise, mental or physical. And the film, as intimate as thought, so long as it is free from the introduction of the alien element of sound, gives this co-operation its best chance. The accompanying music is not an alien sound (Richardson 1998, 161). La projection continue des films est inséparable de la musique d'accompagnement parce que la musique aide à s'y " plonger » : «It [the accompanying music] assists the plunge into life that just any film can give, so much fully than just any play, where the onlooker is perforce under the tyranny of the circumstances of the play without the chances of escape provided so lavishly by the moving scene " (Richardson 1998, 161). La musique d'accompagnement n'est pas un son étranger si elle accompagne en continu le film ou le roman, en s'y fondant. L'accompagnement musical sert de «tissu conjonctif », car sans lui, le public reste passif et n'a rien à quoi rattacher sa conscience créative : «Without it the film is a moving photograph and the audience mere onlookers " (Richardson 1998, 161). Son rôle est de créer le film et de lui donner couleur et son (Richardson 1998, 163). Le public doit être concentré et calme pour pouvoir collaborer, pour « créer le film » et « sa propre réalité »:

For the present music is needed and generally liked even by those who are not aware that it helps them to create the film and gives the film both colour and sound. In our small palace we object to any sound coming from the screen. We dislike even the realistic pistol-shot that was heard once or twice during the period of great ambitions. With the help of the puff of smoke and our pianist's staccato chord we can manufacture our own reality. And since the necessary stillness and concentration depend in part upon the undisturbed continuity of surrounding conditions, the musical accompaniment should be both continuous and flexible. (Richardson 1998, 163)

Dans Clear Horizon, Miriam parle aussi d'accompagnement musical lors d'une récitation de poésie. Selon elle, a priori, l'accompagnement musical suppose une division de l'attention; en d'autres termes, il peut représenter un obstacle. Cependant, pour Miriam, 
il aide à la réception de la poésie. La musique a le pouvoir de démontrer les relations des objets entre eux :

And I asked what he thought of Clifford Harrison, and whether he agreed that musical accompaniment, although in advance it seemed to promise a division of one's attention, actually had the reverse effect, helping, with its unaccentuated flow, to focus and vitalize the images evoked by a poem. And while he was enthusiastically agreeing, I thought of Hypo's definition of music as a solvent and was about to work off on him an interpretation that had just occurred to me, to say that music favoured the reception of poetry partly by causing the shapeless mental faculties that deal with things, to abdicate in favour of the faculty that has the sense of form and sees things in relationship. $(P 4,272)$

Même si Richardson ne parle pas de l'accompagnement musical dans la fiction, elle met cependant sa conception de l'accompagnement musical cinématographique en relation avec ses idées sur le rôle de la musique et du langage dans un contexte plus large. Selon elle, la musique encourage la capacité de vision et le langage la compromet: «Music enhances the faculty of vision [...], [speech brings about] the diminution of the faculty of seeing [...]. Vocal sound is always a barrier to intimacy, is destructive of the balance between what is seen and the silently perceiving, co-operating onlooker " (Richardson 1998, 155).

Alors, qu'entendons-nous par «accompagnement musical» dans Pilgrimage? L'accompagnement musical, surtout dans la fiction, est un sujet négligé par la recherche musico-littéraire contemporaine. Steven Paul Scher mentionne le terme dans son analyse de l'opéra Heaven Ablaze in His Breast de Judith Weir (Bernhart 2004, 498), mais dans un sens musicologique, c'est-a-dire comme soutien: c'est le soutien harmonique et rythmique d'une composition. Or, nous appelons accompagnement musical dans la fiction la musique verbale qui accompagne le déroulement d'un événement ou d'un épisode. Selon la définition de S.P. Sher, dans sa typologie fondatrice des relations musicolittéraires (Bernhart 2004, 28) ${ }^{2}$, la musique verbale est la représentation de la musique en mots; la description (avec ou sans référence directe) d'une œuvre musicale (réelle ou imaginaire) ou une interprétation d'une œuvre musicale dans la littérature (Bernhart 2004, 30). Dans le cas de l'accompagnement musical dans la fiction, la description de l'interprétation d'une œuvre musicale ou la description de l'œuvre ellemême suit et soutient le déroulement d'un événement. Citons pour illustrer cette idée un extrait du premier volume de Pilgrimage, Pointed Roofs (1915). Dans cet exemple, Miriam, professeure d'anglais dans une école de filles en Allemagne, assiste à un événement musical dans l'école, le Vorspieln, et écoute une de ses étudiantes, Clara Bergmann, jouer du piano :

The notes rang out in a prelude of unfinished phrases-the kind, Miriam noted, that had so annoyed her father in what he called new-fangled music-she felt it was going to be a brilliant piece-fireworks-execution-style-and sat up selfconsciously and fixed her eyes on Clara's hands. "Can you see the hands?" she remembered having heard someone say at a concert. How easily they moved. Clara still sat back, her face raised to the light. The notes rang out like trumpet-calls as her hands dropped with an easy fling and sprang back and dropped again. What loose wrists she must have, thought Miriam. The clarion notes ceased. There was a pause. Clara threw back her head, a faint smile flickered over her face, her hands fell gently and the music came again, pianissimo, swinging in an even rhythm. It flowed from those clever hands, a half-indicated theme with a gentle, steady, throbbing undertow. $(P 1,43-44)$ 
Ceci est un exemple de musique verbale, la description de l'interprétation d'une œuvre musicale (sans référence directe): le style, la technique, la position du corps de la pianiste, la nuance de la musique jouée (pianissimo), le rythme. Dans la continuité de l'extrait, pendant que la jeune fille joue du piano et pendant que Miriam l'écoute, elle se souvient en même temps d'une image de son enfance :

Miriam dropped her eyes-she seemed to have been listening long-that wonderful light was coming again-she had forgotten her sewing-when presently she saw, slowly circling, fading and clearing, first its edge, and then, for a moment the whole thing, dripping, dripping as it circled, a weed-grown mill-wheel... She recognised it instantly. She had seen it somewhere as a child-in Devonshire-and never thought of it since-and there it was. She heard the soft swish and drip of the water and the low humming of the wheel. How beautiful... it was fading... She held it-it returned -clearer this time and she could feel the cool breeze it made, and sniff the fresh earthy scent of it, the scent of the moss and the weeds shining and dripping on its huge rim. Her heart filled. She felt a little tremor in her throat. All at once she knew that if she went on listening to that humming wheel and feeling the freshness of the air, she would cry. She pulled herself together, and for a while saw only a vague radiance in the room and the dim forms grouped about. She could not remember which was which. All seemed good and dear to her. The trumpet notes had come back, and in a few moments the music ceased... $(P 1,44)$

Pendant que Miriam se souvient, le jeu de la musique continue et devient un accompagnement musical, c'est-a-dire qu'il accompagne la lecture. Alors, quelle est la fonction de l'accompagnement musical dans Pilgrimage? Pour la protagoniste, la musique ouvre l'accès au " centre de son être ", « à la lumière étrange ", "à la joie indépendante " $(P 1,316)$, et la libère en unissant «le passé et l'avenir et le présent» $(P 1,205)$. Pour le lecteur, si nous prenons en compte les idées de Michel Chion sur l'effet de la musique sur les spectateurs d'un film, nous pouvons dire que l'accompagnement musical sert à susciter de l'empathie chez le lecteur (Chion 1994, 8). Cependant, la musique dans le film et l'accompagnement musical dans la fiction sont deux types différents d'intermédialité. Le premier, en employant le terme de Wolf, est une intermédialité directe où nous avons une combinaison des formes d'expression artistique (Wolf 1999, 54). En revanche, l'accompagnement musical dans la fiction comme forme de musicalisation de la fiction est un type d'intermédialité indirecte (« covert») : «in which music as a non-dominant medium is transformed into or appears in literature, that is, "under the cover" of literary signifiers » (Wolf 1999, 54). Richardson utilise l'accompagnement musical dans Pilgrimage pour assurer la collaboration du lecteur, pour stimuler sa capacité à mettre les choses en relation, et pour qu'ils construisent ensemble (écrivain et lecteur) la "réalité». La " musique verbale » dans Pilgrimage, les morceaux de musique que l'on peut "entendre " au cours du pèlerinage de la protagoniste constituent l'accompagnement musical et rendent possible la collaboration du lecteur. Avec la ponctuation exigeante, la typographie et l'accompagnement musical Richardson invite le lecteur à contribuer à la création de la « réalité ». Le défi de l'écriture est la « vérité »; elle n'en révèle qu'une partie, dit Miriam à la fin du dernier volume, March Moonlight, annonçant son avenir d'écrivain au rythme du dernier mouvement de la dernière sonate de Chopin (le Finale de la Sonate pour piano $\mathrm{n}^{\circ} 3$ en si mineur op. 58) :

[...] the tremendous last movement of Chopin's last sonata encompasses me. Joining forces with my silent lime tree it sets aside all personal problems. [...] While I write, everything vanishes but what I contemplate. The whole of what is called "the past" is with me seen anew, vividly. No, Schiller, the past does not stand "being still". It moves, growing with one's growth. Contemplation is adventure into discovery; 
reality. What is called "creation," imaginative transformation, fantasy, invention, is

only based upon reality. Poetic description a half-truth [...] (P4, 656-657)

C'est au lecteur de recréer l'autre moitié, illuminé par la musique d'accompagnement car : « Without music there is neither light nor colour » (Richardson 1927, 37).

La préoccupation principale de Richardson était l'écriture, la façon dont l'écriture parviendrait à exprimer au plus près la vie, et permettrait une plus grande participation du lecteur. Pour y parvenir, Richardson a développé une approche interartielle et s'est appuyée surtout sur la musicalisation de la fiction : elle a utilisé des procédées poétiques ou musicaux tels que les phrases rythmées et les allitérations; elle a décrit le timbre et le rythme des voix dans le texte par des indications musicales (sotto voce, pianissimo, staccato etc.); elle a joué avec la ponctuation et la typographie en laissant des blancs entre les paragraphes; elle a intercalé des paroles de chansons, de poèmes ou de comptines; elle a décrit des morceaux de musique et la façon de les jouer, des tableaux et d'autres formes d'art, et employé des techniques cinématographiques ${ }^{3}$. Son objectif était de créer un roman moderniste aussi sonore que la poésie, aussi libre que la musique, aussi pictural que la peinture, aussi kaléidoscopique que le cinéma et ouvert à la collaboration du lecteur, à sa contribution créative au processus d'interprétation. Sa démarche n'accorde pas à ces procédés ni aux autres arts (la poésie, la musique, la peinture, le film) qu'elle convoque un statut inférieur et elle ne les réduit pas à de simples outils pour parvenir à ses fins. Au contraire, Richardson montre que le roman permet une traversée intermédiale. Le roman peut également apprendre des autres arts pour se libérer de sa forme et de son contenu traditionnels : « Music and poetry told everything-whether you understood the music or the words-they put you in the mood that made things shinethen heartbreak or darkness did not matter » $(P 1,374)$.

\section{BIBLIOGRAPHIE}

Bernhart, Walter et Werner Wolf (eds). Essays on Literature and Music (1967-2004) by Steven Paul Scher. Amsterdam: Rodopi, 2004.

Chion, Michel. Audio-Vision. Sound on Screen. Claudia Gorbman (trans.). New York: Columbia UP, 1994.

Gillespie, Diane. « Dorothy Richardson (1873-1957) ». The Gender of Modernism A Critical Anthology. Bonnie Kime Scott (ed.). Bloomington and Indianapolis: Indiana UP, 1990, 393-398.

Hanscombe, Gillian. « Introduction » (1979). Dorothy Richardson. Pilgrimage 1. London: Virago

Press, 2002, 1-7.

Marcus, Laura. « Introduction ». Close Up 1927-1933. Cinema and Modernism. James Donald, Anne Friedberg and Laura Marcus (eds.). Princeton: Princeton UP, 1998, 150-159.

Morgan, Louise. « How Writers Work: Dorothy Richardson ». Everyman (22 octobre 1931): 395-400.

Prieto, Eric. Listening In: Music, Mind, and the Modernist Narrative. Lincoln and London: $\mathrm{U}$ of Nebraska P, 2002. 
Richardson, Dorothy. «About Punctuation » (1924). The Gender of Modernism, A Critical Anthology. Bonnie Kime Scott (ed.). Bloomington and Indianapolis: Indiana UP, 1990, 414-418.

Richardson, Dorothy. « Adventure for Readers » (1939). The Gender of Modernism, A Critical Anthology. Bonnie Kime Scott (ed.). Bloomington and Indianapolis: Indiana UP, 1990, 425-429.

Richardson, Dorothy. « Continuous Performance ». Close Up (July 1927).

Richardson, Dorothy. « Continuous Performance: A Tear for Lycidas ». Close Up 7/3 (September 1930). Close Up 1927-1933. Cinema and Modernism. James Donald, Anne Friedberg and Laura Marcus (eds.). Princeton: Princeton UP, 1998, 196-201.

Richardson, Dorothy. « Continuous Performance: Musical Accompaniment ». Close Up 7/3 (September 1930). Close Up 1927-1933. Cinema and Modernism. James Donald, Anne Friedberg and Laura Marcus (eds.). Princeton: Princeton UP, 1998, 162-163.

Richardson, Dorothy. « Data for Spanish Publisher ». London Magazine 6.6 (June 1959): 14-19.

Richardson, Dorothy. « Foreword to Pilgrimage » (1938). The Gender of Modernism: A Critical Anthology. Bonnie Kime Scott (ed.). Bloomington and Indianapolis: Indiana UP, 1990, 429-432.

Richardson, Dorothy. Journey to Paradise. London: Virago Press, 1989.

Richardson, Dorothy. Pilgrimage 1 (1979). London: Virago Press, 2002.

Richardson, Dorothy. Pilgrimage 4 (1979). London: Virago Press, 2002.

Richardson, Dorothy. « The Artist and the World To-Day ». Bookman 86 (May 1934): 94-95.

Wolf, Werner. The Musicalization of Fiction: A Study in the Theory and History of Intermediality. Amsterdam: Rodopi, 1999.

\section{NOTES}

1. Le terme « musicalisation de la fiction » est introduit par Friedrich Schlegel dans son Fragmente zur Poesie und Litteratur (1799-1801) (voir W. Wolf, «Can stories be read as music » dans Telling Stories, Elmar Lehmann and Bernd Lenz (eds.), Amsterdam : Grüner, 1992, 207). Il est également défini par le protagoniste-écrivain Philip Quarels dans le roman Contrepoint d'Aldous Huxley comme: "The musicalization of fiction. Not in the symbolist way, by subordinating sense to sound. [...] But on a larger scale, in the construction» (301). La définition de Northrop Frye (1956) : « [...] a quality in literature denoting a substantial analogy to, and in many cases an actual influence from, the art of music", aussi adoptée par S.P. Scher, sert de point de départ pour W. Wolf (voir W. Wolf, «Can stories be read as music » dans Telling Stories, Elmar Lehmann and Bernd Lenz (eds.), Amsterdam : Grüner, 1992, 212).

2. S.P. Scher a développé le concept et la définition du terme «musique verbale» en 1968 dans Verbal Music in German Literature. Dans son article "Notes Towards a Theory of Verbal Music » (1970), il explique que la caractéristique principale de la musique verbale est sa nature littéraire. 3. On peut consulter Carol Watts, Dorothy Richardson, Writers and their Work Series. Plymouth: Northcote in association with The British Council, 1995. 


\section{RÉSUMÉS}

Cet article tente de cerner les liens établis par Dorothy Richardson entre le roman moderniste, la musique et la musicalisation de la fiction dans Pilgrimage. Cette étude de l'esthétique de Richardson nous permet de conclure que la musique et la musicalisation de la fiction sont étroitement liées à la caractéristique essentielle du roman moderniste selon l'auteure, c'est-àdire la méfiance à l'égard du langage et des conventions du roman traditionnel. Dans Pilgrimage, Richardson tente de mettre en place une collaboration avec le lecteur et d'utiliser la musique comme modèle pour développer son style expérimental.

This article aims to identify the links that Dorothy Richardson established between the modernist novel, music and the musicalization of fiction in Pilgrimage. By analysing the aesthetics of Richardson, we conclude that music and the musicalization of fiction are closely related to the essential characteristic of the modernist novel, i.e. the distrust in language and in the literary conventions of traditional novels. In Pilgrimage, Richardson uses music as a model for her experimental style and to open up space for the collaborative reader and his/her creative consciousness.

\section{INDEX}

Mots-clés : roman moderniste, musique, musicalisation de la fiction

Keywords : modernist novel, music, musicalization of fiction oeuvrecitee Pilgrimage

\section{AUTEURS}

\section{IVANA TRAJANOSKA}

Ivana Trajanoska est docteur en études anglophones de l'Université Paul Valery - Montpellier 3 et maître de conférences à l'Université American College Skopje en République de Macédoine. Elle travaille sur la littérature moderniste et l'intermédialité. Elle a publié un roman en macédonien Razglednici (Des cartes postales), Skopje : Art\&Art, 2008 et quelques articles. 